Robinson, Matthew B. (2003). Justice as Freedom, Fairness, Compassion, and Utilitarianism: How My Life Experiences Shaped My Views of Justice. Contemporary Justice Review (Dec 2003) 6(4): 329-340. Original version available from Taylor \& Francis. (ISSN: 1477-2248) DOI: 0.1080/1028258032000144776

\title{
Justice as Freedom, Fairness, Compassion, and Utilitarianism: How My Life Experiences Shaped My Views of Justice
}

\author{
Matthew B. Robinson
}

\begin{abstract}
This essay lays out my definition of justice and traces the origins of its conception. I identify and discuss very specific life experiences and how they have affected my understanding of justice. Specific incidents include early childhood experiences, key events in adolescence, and the most important episodes from early adulthood. I examine my own family conditions and early relationships and consider the influences of certain television shows and music in childhood and adolescence. I also discuss the effects of various educational experiences. The culmination of these life experiences was the emergence of a very strong sense of justice, reciprocity, and compassion for others, particularly for the least powerful and most vulnerable in our midst. These experiences in essence pushed me into the field of criminal justice and into the worlds of academia and social justice activism. They also allowed me finally to see my mission in life and to understand how all my life experiences have shaped my sense of justice.
\end{abstract}

\section{INTRODUCTION}

The term "justice" has many meanings. To crime victims, for example, justice often means getting even with offenders, "an eye for an eye, a tooth for a tooth." This conception of justice can best be equated with retribution and vengeance. To criminal defendants, justice typically means being treated fairly, so that justice is indeed blind. This conception of justice is best equated with due process. Of course, 
scholars have defined justice in numerous ways and the definition of justice we see in Webster's Collegiate Dictionary (2002) includes the following entries:

the maintenance or administration of what is just especially by the impartial adjustment of conflicting claims or the assignment of merited rewards or punishments;

the administration of law ... the establishment or determination of rights according to the rules of law or equity;

the quality of being just, impartial, or fair ... [and] the principle or ideal of just dealing or right action.

Finally, justice means "conformity to truth, fact, or reason."

I have my own conception of justice which is consistent with many of the above definitions. My sense of justice emerged early in life and has evolved over the years. In this essay, I offer my definition of justice and discuss specific life experiences that led to its emergence. Of course, there is no way to fully account for all the experiences that are relevant to a person's sense of justice; there are undoubtedly forgotten events and incidents, and others which a person might not even be aware of. The experiences I talk about here are those of my daily consciousness, those I carry around with me and often think about, and which are important because they remind me of the bases for how I live each day.

\section{WHAT IS JUSTICE?}

The concept of justice is best depicted by the familiar image of Justicia, the lady justice who adorns many buildings across the world. As I wrote in my book, Justice Blind (2002), the sword held by Justicia shows that justice symbolizes the threat of punishment, even physical punishment. This is proof that justice depends upon punishing offenders. Her scales are a clear reference to weighing the competing interests of the state and the individual. This is proof that justice depends on fairness. Finally, the blindfold suggests Justicia is blind or ignorant to factors such as race, social class, gender, and so forth.

From this mythical figure, it is apparent that doing justice implies at least three things: (1) that guilty people will be punished for their wrongful acts (what I called justice as an outcome); (2) that individual rights will be protected in order to prevent innocent persons from being wrongly subjected to criminal punishment (what I called justice as a process); and (3) that all people are treated equally under the law, and we will "advance principles of fairness, equity, reasonableness, and so forth, through police, court, and correctional practices" (Arrigo, 1999, p. 253). This is called social justice. Social justice exists when all forms of culpable harmful behaviors are abhorred, opposed, denounced, combated, and abolished (Barak \& Henry, 1999).

When these three conceptions of justice are combined into one, my view of justice can be understood. To me, justice means: holding the guilty accountable for their behaviors when an actual harm results; taking reasonable steps to ensure that no innocent people are wrongly subjected to criminal 
punishment; and treating all people equally and without regard to extralegal factors such as race, social class, and gender. This conception of justice is made up of three elements that appear to conflict with each other but do not in fact when pursued as part of a rational, planned approach to criminal justice policy (Welsh \& Harris, 1999).

First, holding the guilty accountable is fundamental to any understanding of justice. I believe a state response is necessary to combat criminal behaviors but only when they actually cause some form of harm to people. Thus, to me, pursuing white-collar, corporate, and nation-state crimes is much more important than pursuing street crimes because the former cause far more physical and financial damage. Additionally, according to my definition of justice, it makes little sense to go after people engaged in "victimless crimes" (acts which by definition have no victim) because the people who engage in them are willing participants. People are free to do as they like as long as they hurt no one else. Second, constitutional protections must be respected in order to ensure that no one is wrongly convicted and punished which, in my opinion, is the worst form of injustice. Finally, as part of my appreciation of social justice, I believe governments have a responsibility to alleviate the suffering of their people whenever possible, to reduce harms however possible, and carefully to create policies that in no way interfere with basic human rights.

This is an interpretation of justice based on the principles of freedom, fairness, compassion, and utilitarianism, or doing the greatest good for the greatest number of people. According to this view of justice, not even our criminal justice policies can be tolerated when they interfere

with social justice; destructive criminal justice policies based on vengeance ought to be replaced with restorative justice practices based on forgiveness and restoration.

\section{THE EMERGENCE OF JUSTICE}

How did I arrive at this understanding of justice? From where did it emerge? As I think back on my life, I see that I was exposed to this view of justice very early on, and many of my life experiences have served to strengthen this comprehension of justice. In the sections that follow, I outline key occurrences from early childhood, adolescence, and early adulthood that I believe were fundamental to the emergence of this vision of justice.

\section{Early Childhood Experiences}

When I was about six years old, my parents were divorced. Neither my brother (aged seven) nor I could understand this event at the time; in fact, I did not really begin to understand it fully until I was in my mid and late 20s. As a criminological theorist, I now know that virtually every study of family disruption finds a positive relationship between divorce and antisocial behavior. Children from "broken homes" are less well psychologically adjusted, have lower self-esteem, and do not perform as well in school. The 
effects of family disruption seem to be worse when family discord or break-up occurs early in a child's life, as it did in mine (Robinson, 2004).

I did not, at the time, feel like my parents' divorce was setting me up for any exposure to negative conditions, or that I would somehow be at a disadvantage relative to my peers. It would, consistent with the research, lead to problems in my life that would dog me for 20 years-relationship problems in adolescence and early adulthood, early alcohol abuse, chronic anxiety, and similar difficulties. Given that these problems greatly influenced my conception of justice, my parents' divorce is the most significant event in its formulation. This occurrence, more than any other, has left me very sensitive to harms suffered by others and empathetic to people in need.

I was, in fact, lucky to be raised by a strong mother who worked hard to raise her two sons. She somehow instilled a strong sense of compassion in both of us. Each of us, like our mother, has gone into a helping profession. My mother Randa has a master's degree, is a lifelong gerontologist, and has held many high-level positions organizing, providing, and studying effective services for the elderly. My brother Brandt has a master's degree, is a high school teacher, athletics coach, and has always been highly involved in community service. And I am a university professor who studies, teaches, does research, and provides service related to justice. I also work in the community for social justice.

I don't have many memories of my early childhood other than through the many pictures I have seen, which is strange but understandable in retrospect. Some of my recollections are positive, such as the dozens of gifts my parents would give me at Christmas, far too many for one child. We were very well off financially in my early childhood and had everything we wanted.

Yet most of my most vivid memories revolve around negative experiences, such as being picked on and bullied. I do recall a prophetic conversation with my mother when I was a young child, when she told me that I would have to work harder than most children, that more would be expected of me because I was the child of a single parent. "You don't have a father to bail you out like most kids do," my mother said to me on many occasions. Even then, I recall thinking how unfair that was. At any early age, I was becoming aware of unfairness and was truly bothered by it. Children do not have effective ways to deal with such realizations so I am not sure how I dealt with this but, in some ways, am now thankful for it because I believe it made me a more just person.

After my parents' divorce, we moved from a very large house in North Carolina to a much smaller apartment in Florida. My mother started graduate school and, in essence, her career, while my brother and I began living in a single-parent family with far fewer resources. My mother did her best to provide us with a solid upbringing-which we got. She specifically expressed the value of an education by providing us with lots of books, encyclopedias, and magazines to satisfy our curiosity about the world. We also enjoyed opportunities to participate and excel in athletics. Living in apartment communities also provided numerous unique opportunities, such as playing in apartment complex football leagues and singing with some other boys in an impromptu group. At the age of 10, I was singing rap songs with two of my best friends, African American twins from the neighborhood. While white rappers are not 
unusual now, they were in 1980. Perhaps this is why we were permitted to sing one rap song over the intercom at school after the pledge of allegiance in the fifth grade.

Despite these positives, we clearly were disadvantaged, having only one parent (who worked full-time and then some) to supervise us, monitor our behavior, and correct us when we broke the rules. As I began to understand the advantages I did not enjoy, I certainly became more sympathetic to people facing disadvantages of all kinds. This, I believe, is at the root of my conception of justice.

My mother also made sure that Brandt and I watched the local and national news from a very early age, as well as the original news magazine television show, 60 Minutes. Even now, I don't understand how or why this happened but doing so certainly gave both of us children a broader appreciation of the world, which I also think lays at the heart of how I see justice. I also religiously watched television shows dealing with crime and criminal justice, including Perry Mason, Gunsmoke, CHiPs, Hawaii 5-0, Hillstreet Blues, Quincy, and others. Looking back, these shows all fed my sense of justice.

For example, Perry Mason was about the defense attorney who in all cases except a handful represented a client charged with murder. In virtually every case, this lawyer adamantly fought for the rights of his clients, despite overwhelming evidence of guilt, and ultimately got them acquitted, and rightly so because they were all innocent.

Gunsmoke was about the very burly Marshall Matt Dillon, who ruled Dodge City with a sense of compassion and justice. In nearly every episode, Marshall Dillon fought against the bad guy, using force only when necessary for self-defense. Of course, right always won in the end. I was, according to my mother, named after this fictional Matt Dillon character, although I did not know it at the time.

CHiPs was about the daily exploits of two motorcycle officers of the California Highway Patrol. Although comedic in nature, the episodes depicted two honest officers who never broke any rules in order to catch the bad guy. Officers Ponch and John were directed only by their sense of justice, and always did the right thing even when it got them into trouble.

Hawaii 5-O centered around the crime-fighting exploits of Captain Steve McGarett, Danny "Danno" Williams, and fellow investigators and officers in an elite state police agency in Hawaii. This show always featured a hard-working police force operating within the confines of the criminal law to outwit the criminals and to catch them in the end, so that McGarett could say, "Book 'em Danno, murder one."

Hillstreet Blues was one of the first widely watched police shows on television, and was about the daily life of officers in a police precinct. Although the individual characters had different views about what was right and acceptable police behavior, they all tended to be motivated by their desire to bring justice to the neighborhood and world. Many episodes featured the battles of Captain Frank Furillo and a lawyer from the Public Defender's office, Joyce Davenport, and every episode began with a roll call and the familiar words by Sergeant Phil, "Let's be careful out there."

Quincy was about the Los Angeles Coroner's office and the county medical examiner, Quincy. Almost every episode featured an unsolved murder or mysterious death that was solved by this hard-working 
man who was as much a crime fighter as a medical examiner. In this show, Quincy always had time to do what was right, even against the direct orders of his superior, because justice was the only thing that really mattered.

In each of these shows, the main themes were: it is acceptable and at times necessary to question authority and to resist bureaucracy as long as justice is achieved in the end; oppression in all its forms must be fought; justice demands standing up for what is right even when it is not popular; even though sometimes innocent people get caught up in the system we always get it right in the end; and sometimes the work of one person will bring about justice.

More than just creating an interest in criminal justice as a field of study, these shows informed how I saw justice. Justice was struggling to do what is right, no matter how popular or unpopular it is with others. Justice was fighting for freedom, being fair, having compassion for human beings, and doing good for all humankind.

\section{Adolescence}

As we grew up, my brother and I both worked for our own spending money, but occasionally the money would also be used to help pay bills. Beginning in high school, both Brandt and I began to realize that we felt different from the other kids. This was not something we would talk about until much later, after college in fact. But looking back, I can see that I was beginning to understand justice. Mostly, we felt less privileged, that it was not fair, and we were resentful about it. But, because of our mother, we also appreciated how good we had it relative to others in the world.

My adolescence was very tumultuous. First, I suffered from weekly migraine headaches that at times were incapacitating. I had other serious medical problems that seemed to hold me back just enough to bother me. Second, I had a lengthy relationship as a teenager with a young woman who would end up breaking up with me from far away while on summer vacation with the result that I had difficulties with committed relationships. Additionally, her next boyfriend stalked me and threatened me with physical violence for more than a year, mostly because I would not back down. This chronic bullying left me anxious, more introverted, afraid to go to school, and very angry. Yet this victimization provided me with a greater understanding of the victim's conception of justice. I now look back on such experiences with appreciation for they would ultimately lead me toward my current career.

Even though I did not have a father in my life, a distant relative kept track of me and Brandt from afar. He sent us money for our birthdays and holidays, and attended our graduations even though it meant he had to fly at his own expense from Wyoming to Florida. He also took Brandt and me out to Wyoming to visit and to go on a tour of four or five states out west. This man, my great uncle Ware, would also influence how I see justice but, again, I would not realize it until later in my life.

It is because Ware's contribution to my life is so commendable that makes his part so important. My grandmother (my father's mother) committed suicide when my father was an infant. My grandfather quickly remarried and my father was sent off to boarding schools. Yet, my father's uncle, Ware-who is my great uncle-stayed involved in my dad's life even though his sister was deceased. Imagine an uncle 
insisting on staying involved in his nephew's life, even though his sister was now dead and the nephew lived in a faraway state. Ware cared about family so much, even distant family, that he was able to put the pain of his own loss aside in order to play a role in my father's life.

Amazingly, after my father married my mother and we were born, Ware also sought to play a role in our lives. That Ware was deeply religious - he was an Episcopalian minister-may explain his devotion to all of his family across the country. Yet, as I would later learn, it was more than that. I now understand that it was Ware's devotion to humanity that required him to be so just. My brother and I now understand this but did not when we were in high school.

During high school, my brother went on a Caribbean cruise and returned with new music. He had an audiotape of a musical group I had never heard of, the Melody Makers. As it turns out, this is the band of David "Ziggy" Marley, son of the late reggae superstar Bob Marley of the Wailers. I remember listening to this tape again and again, not liking it at first, but growing to love it for the fact that it was different than anything I had ever heard. Up until this point, I listened mostly to the radio, as well as my rap tapes, and songs from "activist" rock bands such as U2.

From this point forward, I would never stop listening to reggae and it would influence my understanding of justice. A large portion of the music I listened to in adolescence and since is what I like to call "intellectual" and "activist" music. It comes from artists such as U2, Bob Marley, Ziggy Marley and the Melody Makers, Steel Pulse, Pato Banton, Jimmy Cliff, Rage Against the Machine, and similar artists and bands. Much of this music is specifically about harms suffered by powerless people and is aimed at recognizing and ending oppression, suffering, and injustices of all types. It is informed by and is about world events such as South African apartheid, racism, discrimination, war, police brutality, wrongful imprisonment, government oppression, and so forth, and encourages its listeners to be active in world events and engaged in the practice of justice.

An amazing thing about music is that it allows us to make sense out of our own life experiences, even including things we have read. Having read works by the Reverend Martin Luther King, Jr., Mahatma Gandhi, and various philosophers in high school, I gained a rudimentary understanding of issues related to human rights and justice, but I could not feel these issues until these groups put them into music. Many of King's words inspired me, especially his famous letter from a Birmingham jail. There, King wrote, "an injustice anywhere is a threat to justice everywhere." A quote from Gandhi reminds me that justice always wins in the end. He said: "When I despair, I remember that all through history, the way of truth and love has always won. There have been murderers and tyrants, and for a time they can seem invincible. But in the end, they always fall." These words speak to my view of justice: I am troubled by stories of injustice anywhere in the world but I believe that justice will triumph. What is right and just always comes to fruition, not because it is inevitable as Gandhi's words seem to suggest, but because of the work of people such as Gandhi, King, and normal, everyday people who are dedicated to justice.

Of all the moving and just songs I have been influenced by, the lyrics of one song in particular stand out. It is "Justice" by Ziggy Marley and the Melody Makers, from a 1989 album. The song reads, in part: 
Judge me if I am weak, judge me if I am strong, judge my days and all life long. They let the baby cry, let the mama cry and youths like I and I have to cry for justice. One, one, one word prayer, justice is like a good friend who long time we don't see, why they taking liberty, with I and I and I justice ... now not later, justice ... justice where are you, justice, look what they do. They make the innocent cry the innocent cry . . . they make the innocent die the innocent die . . . the more the tears the more, the more we want, justice, justice...

This song is specifically about injustices suffered by Marcus Garvey (an African American who created an international organization aimed at bettering the lives of blacks) and Steve Biko (a South African who unified numerous organizations against apartheid), at least those are the ones mentioned in the song. But, this song, more than any other I can remember, convinced me that these musicians were in pain because of injustices that people like them had suffered. It is clearly about the struggle of Africans and African descendants to be treated as equals by whites. It equates justice to prayer, questions where justice is for the common man, and specifically names troubling injustices. Such music made me curious about figures such as Marcus Garvey and Steve Biko, and led me to read about them and others who ultimately informed my view of justice.

Steve Biko's story is chronicled in the 1987 movie Cry Freedom, a stirring account of his life and death under South African apartheid. I've always been drawn to movies that show the underside of human nature and how everyday people respond to it, including Do the Right Thing, Boys ' $n$ the Hood, and other stories that show people (particularly poor and minority people) triumphing over injustices.

\section{Early Adulthood}

After graduating from high school, I meandered off to Florida State University (FSU) to become a marine biologist or oceanographer (so I thought). All that reading about animals in my magazines and encyclopedias as a child led me to want to work with animals, who, unlike humans, seemed so much more just. Human beings, it turns out, are probably the only species on the planet that will kill another of their species after it is defeated and has surrendered, unless of course, it is being killed for food or mating privileges.

Being at college was the first time I would be away from home and, since I had just made a new group of friends the summer before leaving, I was isolated in a new and scary environment. I turned to alcohol to deal with the anxiety and depression of being alone, which made academic success unlikely. I struggled as much, if not more, with being independent, living in a scholarship house with more than a dozen other men (all older than me), than with the five honors math and science classes I took in my first semester. When my mother came to collect me for the Christmas holidays, I told her I wanted to come home for good, and I did.

After a semester off, I enrolled at a junior college in my home town and bandied about for two or three semesters not really knowing what my future would hold. I was going to the gym daily, running, and working to earn spending money. At the junior college, a police training facility was operated. One day 
as I was walking in the gym a trainer approached me and said, "We could use someone like you." This intrigued me enough to inquire at the career counseling office as to what I would need to do to transfer back to FSU in order to major in criminology so that I could become a police officer, like Sheriff Matt Dillon, officers Ponch and John, Detectives McGarett and Danno, the many officers on Hill Street Blues and the crime-fighting coroner Quincy. Suddenly I had some direction and began to realize that justice would be my career and ultimately my calling. All I needed was a 2.0 GPA and to be accepted back to FSU, each of which I managed to accomplish.

At FSU, in my first semester back, I was exposed to a very important book in my criminology course with Professor Ted Chiricos-Jeff Reiman's (1998) The Rich Get Richer and the Poor Get Prison, an ideological book about what is wrong with criminal justice in America. One of the main points of the book is that we focus on street crimes at the expense of ignoring real harms or what Reiman called "crimes by any other name."

This stayed with me as I took other classes such as law enforcement, where I learned about the daily life and work of police officers. "How can I be a cop," I remember asking myself, "and go through this all day, every day, and yet, not even go after the real criminals, the ones who manufacture deadly products and take our money through corporate and white-collar crimes?" Suddenly, I found myself in a state of confusion about what I would do once I graduated from college. I wanted to bring about justice by holding the most guilty accountable for their harms, not some petty street criminals.

At this time, I met and began dating another student. She and I dated for three years before we got married. She would also study criminology and criminal justice. Before either of us could finish our studies, my brother was given a devastating diagnosis. Brandt literally went crazy and was diagnosed with bipolar affective disorder, a mental illness that now affects more than one million Americans. He had delusions, was paranoid, suffered from hallucinations, and had unstable moods. Brandt was hospitalized for more than a month, and it took years under various types of medication and counseling for my brother to be functional enough to be independent again. Brandt is a success story, for he eventually went back to graduate school, earned a master's degree in history, and is a now an excellent high school teacher. He remains very active in community service and is dedicated to a similar sense of justice.

My experience with my brother's mental illness forced me to become knowledgeable about mental illnesses (which are brain disorders), and led me to become very active with the National Alliance for the Mentally III (NAMI). In order to deal with my brother's illness and to learn about mental illnesses generally, I began reading everything I could get my hands on that dealt with brain disorders. In so doing, I learned that people with mental illnesses are over-represented in the nation's criminal justice system. More than $15 \%$ of the nation's prison and jail inmates are mentally ill. When the nation's mentally ill populations were released from state hospitals in the 1960s and 1970s, it was expected that they would get treatment in their communities, but community treatment programs were not widely available. In places where such programs were available, systems were not in place to ensure that the people who needed them would obtain treatment. I learned that we use our systems of criminal justice to deal with the problem of mental illness. 
Given that people with mental illness are no more responsible for their suffering than those that suffer from heart disease or cancer (and typically less so), this is a shameful practice that is clearly unjust. I decided my life would be devoted to ameliorating hypocritical conditions such as these, but at this point I was not sure how my devotion would manifest itself in practice.

After earning a bachelor's degree in criminology, I received a package in the mail from my great uncle Ware. He sent me the police club used by my great, great grandfather when he was a member of the Royal Canadian Mounted Police. I did not even know the person's name inscribed on the club, much less that he was a relative and a police officer. I remember thinking, "I guess this justice stuff is really in my blood." Also included in the package from Ware was a letter describing his travels to and from a federal prison to counsel prisoners. In essence, Ware challenged me to change the way we run criminal justice in America. Just as I had read in the words of great philosophers before him, Ware was telling me that the good of a nation could be judged by how it treated its most vulnerable citizens. He described how these prisoners were human beings who deserved humane treatment. Ware charged me to do something about it.

After being convinced by Ware that justice was now my destiny, and also not being able to find good work related to my studies, I decided to return to FSU for graduate studies in criminology. Here, I would be exposed to many great professors and books about justice which would influence my thinking about it. My major professor for doctoral studies, Professor Fred Faust, was the most notable. He not only spent a great deal of time mentoring me and guiding my studies, but also taught me about the concept of humane incapacitation, his major suggestion for criminal justice reform. Faust believed that virtually all of our efforts should be directed at preventing antisocial behavior rather than reacting to it with police, courts, and corrections. For those offenders who still emerged and could not be rehabilitated, Faust suggested humane incapacitation-losing their freedom but not being subjected to brutality, violence, or other destructive influences that deny people their humanity. He also thought they should be allowed to pursue fulfilling activities while incarcerated. After careful consideration, I was convinced that Faust was right, and this would reinforce the impressions of justice I heard and saw in my music, movies, and television shows.

One of the most notable books I read in graduate school was Packer's (1968) The Limits of the Criminal Sanction. I carefully studied Packer's two fictitious models of criminal justice-the crime control model and the due process model-two extremes of criminal justice practice, each based on a different conception of justice. When I studied these two models of justice, I saw that justice could be viewed as both an outcome and as a process. What I came to call justice as an outcome is commonly referred to as distributive or corrective justice. This conception of justice requires that the guilty be held accountable, and is thus identical to what crime victims think of when they hear the word justice. Packer discussed this form of justice as retribution or vengeance. Vengeance is a natural human emotion and is based on the desire to get even with the offender, to give the offender his or her "just desserts." Retribution deals with a more rational approach to justice. It assumes that when an offender commits a harm against a victim, he or she has gained an unfair advantage which he or she is not entitled to under law. Thus, in order to rebalance the scales of justice, punishment must be administered to counteract the advantage gained through crime. In essence, when rules are broken, rule breakers must be punished. 
Justice as a process is concerned with ensuring that everyone is treated fairly and equally while being processed through the criminal justice system by abiding by due process and protecting individual constitutional rights. This requires not allowing discrimination based on factors such as race, class, gender, and so forth. In essence, this image of justice requires that government agencies will be fair, impartial, non-discriminatory, unprejudiced, and unbiased. It is commonly referred to as procedural justice. Packer favored this conception of justice as he argued that criminal justice practice should be consistent with the due process model of criminal justice.

It is clear from my definition of justice that I believe in both of these forms of justice-justice as an outcome and justice as a process. Yet, as Packer acknowledged, being good at one necessarily means being bad at the other, as efforts to achieve one of these forms of justice typically tend to interfere with the realization of the other. Consider the fight against terrorism, for example. Eroding constitutional protections to enable law enforcement agencies to investigate suspected terrorists more fully may make Americans safer from terror victimization but, by definition, it makes us less free. Conversely, requiring law enforcement agencies to follow strict codes of procedure before they can act may "handcuff the police" or make it more difficult for them to apprehend suspected criminals, which could make us more vulnerable to terrorist acts.

We must all decide, then, as Packer (1968) encouraged us to do, which model to embrace. In graduate school, I was already leaning in the direction of due process over crime control, because of three things I learned in my classes about a crime control model of justice: (1) it is typically still ineffective at crime control; (2) it tends to ignore the most harmful acts committed against us; and (3) it directly threatens the most important type of justice, social justice. I learned through Packer's book about the inherent limits of the criminal sanction, which inhibit us from having much of an effect on crime. I also saw even more clearly in graduate school how our criminal laws disproportionately call for the punishment of ordinary street criminals, whose harms are greatly outweighed by white-collar, corporate, and nationstate crimes. And I came to see how our systems of police, courts, and corrections are disproportionately used against the nation's poor and minorities, thereby harming efforts at social justice.

Upon receiving a master's degree, I began teaching at a community college and working simultaneously as a teaching assistant at Florida State. I taught about 25 classes in three years and in the process, therefore, read just about every book that was suitable for introductory criminal justice classes. I found myself continuously frustrated by the lack of what I thought were realistic textbooks that told the truth about our nation's criminal justice systems.

This brings me up almost to the current day. In 1997, I took my first and still only faculty position as Assistant Professor of criminal justice at Appalachian State University. Only six months into my career, my wife dropped a bombshell on me when she told me she wanted a separation. After she had been gone only one week, I learned she had been having an affair and wanted a divorce. This sent me into the most stressful, gut-wrenching period of my life. Remarkably, I read research which showed that across most cultures, losing one's spouse through divorce or death is one of the greatest losses a person can suffer. I re-evaluated my life and literally tried to reinvent myself. At first I was not sure if I would even 
survive it, for I was dedicated to never getting divorced and repeating the mistakes of my father. This was my greatest personal failure ever and nearly led to my death.

For some reason, unknown to me even now, I realized I was being given the first real opportunity in my life to practice what I had been preaching in the classroom for several years-justice based on forgiveness. I decided to forgive my wife for her transgression, I acknowledged my part in the whole mess and I moved on slowly, day by day. Shortly thereafter, I attended an international conference on victimology and learned more about forgiveness, restorative justice, and similar practices, and was shocked to hear papers being delivered about the messages of Gandhi, Martin Luther King, Jr., and other key figures in my life. I learned that research shows that restorative justice based on forgiveness allows families harmed by murder and drunk driving victims to heal more quickly from their losses. I learned about South Africa's Truth and Reconciliation Commission, headed by Bishop Desmond Tutu, and thought: if black South Africans can forgive the white government for kidnapping and killing their innocent relatives in order to bring about closure, why cannot the U.S. pursue a similar strategy in criminal justice? Now I knew that my view of justice held promise because it offered hope as an alternative to our vengeful and punitive criminal justice system.

For the first two years in my faculty position, I taught exclusively in my areas of expertise (criminological theory and crime prevention) but ultimately began developing and offering new courses. One course, in particular, "Injustice in America," allowed me to crystallize my view of justice over the course of a semester. Each day I sat down and wrote about the things we had talked about in class. The result was my 2002 book, Justice Blind?, which I mentioned at the outset of this essay. I also developed new courses such as "The War on Drugs" and "The Death Penalty." Careful study in these areas led me to believe that wars, whether they are fought against drugs or crime generally, are ineffective and unwise, mostly because of the injustices they create.

Only a year after my separation, I met Holly, who I would later marry. Although I never thought I would remarry, I suddenly found myself with my soulmate. Holly earned a master's degree and has been a manager for a local domestic violence shelter, a counselor for inmates, a counselor for victims of domestic violence, and has run a program to reduce underage drinking. She is doing justice locally through her community activity. Being a partner to Holly reminded me of the importance of basic compassion for actual people and convinced me that my justice-related activities in the classroom and in my research must be brought into the real world or else they mean little.

In order to achieve justice as an outcome and as a process, and to encourage social justice-justice that is centered on freedom, fairness, compassion, and utilitarianism - I founded a Social Justice Center on my campus. Its mission is to bring about social justice through teaching, research, and service to the community. So far, we have only a few members and have been mostly concerned with organizational issues. But we are dedicated to bringing about the type of justice discussed in this essay. Our first activities were campus and community events relating to the proposed war and human rights violations in Iraq and Israel. After the war on Iraq began, we joined with other local organizations and organized and participated in dozens of events, each aimed at explaining how and why the war was unjust and should end. Each of us shares a view of justice like that laid out here. 


\section{CONCLUSION}

In this essay, I put forth my conception of justice, which I defined as: holding the guilty accountable for their behaviors when an actual harm results; taking reasonable steps to assure that no innocent people are wrongly subjected to criminal punishment; and treating all people equally and without regard to extra-legal factors such as race, social class, and gender.

Putting this view of justice into practice would call for pursuing white-collar, corporate, and nation-state crimes more than we currently do, as well as street crimes that actually cause harms. The focus, however, would be on prevention rather than the reactive mechanisms of police, courts, and corrections, since crime control is mostly a failure. It would also lead to decriminalizing victimless crimes that cause little harm and which are engaged in by consenting adults. Most important, my view of justice requires strengthening constitutional protections and making greater efforts to alleviate people's suffering, of any kind, whenever possible. This can only be done when we carefully create policies that in no way interfere with basic human rights.

As I suggested in this essay, my view is an interpretation of justice based on the principles of freedom, fairness, compassion, and utilitarianism, or doing the greatest good for the greatest number of people at all times. According to this view of justice, not even our criminal justice policies can be tolerated when they interfere with social justice, and destructive criminal justice policies based on vengeance ought to be replaced with restorative practices based on forgiveness and restoration.

\section{References}

Arrigo, B. (Ed.). (1999). Social justice, criminal justice: The maturation of critical theory in law, crime, and deviance. Belmont, CA: Wadsworth.

Barak, G. and Henry, S. (1999). An integrative-constitutive theory of crime, law, and social justice. In B. Arrigo (Ed.), Social justice, law, crime, and deviance (pp. 201-35). Belmont, CA: Wadsworth.

Packer, H. (1968). The limits of the criminal sanction. Stanford, CA: Stanford University Press.

Reiman, J. (1998). The rich get richer and the poor get prison: Ideology, class, and criminal justice. Boston, MA: Allyn \& Bacon.

Robinson, M. (2002). Justice blind? Ideals and realities of American criminal justice. Upper Saddle River, NJ: Prentice-Hall.

Robinson, M. (2004). Why crime? An integrated systems theory of antisocial behavior. Upper Saddle River, NJ: Prentice-Hall.

Webster's Collegiate Dictionary. (2002). Available online at http://www.w-c.com

Welsh, W. and Harris, P. (1999). Criminal justice policy \& planning. Cincinnati, OH: Anderson. 


\section{Biography}

Matthew Robinson received a PhD in Criminology and Criminal Justice from the Florida State University and is Associate Professor in the Department of Political Science and Criminal Justice at Appalachian State University. He has published widely in the areas of criminological theory, crime prevention, criminal victimization, and the injustices of the criminal justice system. His books include Justice Blind? Ideals and Realities of American Criminal Justice (2002), Why Crime? An Integrated Systems Theory of Antisocial Behavior (2004), and Spatial Aspects of Crime: Theory and Practice, co-authored with Derek Pauslen (in press). He has served on the Board of Directors for the Southern Criminal Justice Association (SCJA) and is now the organization's President. 